\title{
Inter-annual growth of Arctic charr (Salvelinus alpinus, L.) in relation to climate variation
}

\author{
David M Kristensen ${ }^{1}$, Thomas R Jørgensen ${ }^{2}$, Rasmus K Larsen ${ }^{3}$, \\ Mads C Forchhammer ${ }^{4}$ and Kirsten S Christoffersen*3
}

\begin{abstract}
Address: ${ }^{1}$ Dept. of Medical Biochemistry and Genetics A, Panum Institute, University of Copenhagen, Blegdamsvej 3, DK-2200 Copenhagen, Denmark, 2Dept. of Veterinary Pathobiology, Royal Veterinary and Agricultural University, Stigbøjlen 4, DK-1870 Frederiksberg C, Denmark, ${ }^{3}$ Freshwater Biological Laboratory, Institute of Biology, University of Copenhagen, Helsingørsgade 51, DK-3400 Hillerød, Denmark and ${ }^{4}$ Dept. of Arctic Environment, National Environmental Research Institute, Frederiksborgsvej 399, P.O. Box 358, DK-4000 Roskilde, Denmark

Email: David M Kristensen - moebjerg@imbg.ku.dk; Thomas R Jørgensen - jorgensen.thomas@gmail.com; Rasmus K Larsen - rlarsen@ouce.ox.ac.uk; Mads C Forchhammer - mcf@dmu.dk; Kirsten S Christoffersen* - kchristoffersen@bi.ku.dk

* Corresponding author
\end{abstract}

Published: 27 August 2006

BMC Ecology 2006, 6:10 doi:10.1186/1472-6785-6-10

This article is available from: http://www.biomedcentral.com/1472-6785/6/10

(C) 2006 Kristensen et al; licensee BioMed Central Ltd.

This is an Open Access article distributed under the terms of the Creative Commons Attribution License (http://creativecommons.org/licenses/by/2.0), which permits unrestricted use, distribution, and reproduction in any medium, provided the original work is properly cited.
Received: 20 March 2006

Accepted: 27 August 2006

\begin{abstract}
Background: Major changes in climate have been observed in the Arctic and climate models predict further amplification of the enhanced greenhouse effect at high-latitudes leading to increased warming. We propose that warming in the Arctic may affect the annual growth conditions of the cold adapted Arctic charr and that such effects can already be detected retrospectrally using otolith data.

Results: Inter-annual growth of the circumpolar Arctic charr (Salvelinus alpinus, L.) was analysed in relation to climatic changes observed in the Arctic during the last two decades. Arctic charr were sampled from six locations at Qeqertarsuaq in West Greenland, where climate data have been recorded since 1990. Two fish populations met the criteria of homogeny and, consequently, only these were used in further analyses. The results demonstrate a complex coupling between annual growth rates and fluctuations in annual mean temperatures and precipitation. Significant changes in temporal patterns of growth were observed between cohorts of 1990 and 2004.

Conclusion: Differences in pattern of growth appear to be a consequence of climatic changes over the last two decades and we thereby conclude that climatic affects short term and inter-annual growth as well as influencing long term shifts in age-specific growth patterns in population of Arctic charr.
\end{abstract}

\section{Background}

The number of Arctic charr (Salvelinus alpinus, L.) phenotypes varies considerably within and across localities on Disko Island off the west coast of Greenland [1,2]. Two landlocked populations have been described here as well as dimorphic populations with an anadromous morph and a resident morph in rivers $[1,2]$, but whether the two morphs are reproductively isolated remain unclear. The resident and landlocked populations are isolated in the same locality throughout their entire life cycle, thereby presenting an excellent opportunity to investigate differential effects of abiotic factors on somatic growth. 
Fish are ectotherms and hence rely exclusively on external sources of heat. Metabolic produced heat is rapidly lost through the gills and the epidermis and consequently body temperature fluctuates closely with changes in the ambient water temperature [3]. Indeed, since the metabolic processes within the animals are strongly temperature dependent [4], ambient water temperature exerts a major influence on all physiological and behavioural processes in the fish. Moreover, temperature has a nonlinear effect on physiological responses, with an identifiable optimum-rate, and it has been argued that the thermal niche of a fish should considered in much the same way as for example a food resource [5]. Also, it has been shown that that ovulation in charr markedly decreases above $8^{\circ} \mathrm{C}$ and is inhibited at $10^{\circ} \mathrm{C}$ [6]. Finally, maintaining fish above $5^{\circ} \mathrm{C}$ for several weeks results in reduced quality of the eggs $[7,8]$. Hence, relatively small absolute changes in ambient temperature may induce profound changes in the life history traits of the Arctic charr.

Major changes in climate have already been observed in the Arctic and climate models predict further amplification of the enhanced greenhouse effect at high-latitudes leading to increased warming $[9,10]$. In the present study, we propose that warming in the Arctic may affect the annual growth conditions of the cold adapted Arctic charr and that such effects can already be detected retrospectrally using otolith data. To evaluate this hypothesis in 2004 we sampled fish and otoliths from populations at several localities at Disko Island, where the local climate shows an increasing trend in temperatures in the period 1990 to 2004 [10]. Finally, we compare the age specific growth in 2004 with age specific growth data sampled in 1990 [2].

\section{Results \\ Description of the two homogenous and landlocked populations}

The investigations of population structure using Principal Component Analysis (PCA) showed that only one morph inhabited the landlocked localities Røde Elv $\left(69^{\circ} 16^{\prime} \mathrm{N}\right.$, $53^{\circ} 29^{\prime} \mathrm{W}$ ) and Kangarssuk (69 $\left.16^{\circ} \mathrm{N}, 53^{\circ} 50^{\prime} \mathrm{W}\right)$ [see Additional file 1]. Therefore, only individuals sampled from these two populations were used in the analysis. All individuals from both localities had parr marks characteristic of fish that have not smoltificated. The individuals from Røde Elv were small, ranging in size from 82 to 169 $\mathrm{mm}$, and had large eyes and ventrally placed mouths. Despite their small size, a number of fish in Røde Elv were ready to spawn, a feature common to both populations. Specific for all fish sampled at Kangarssuk were large external, infectious wounds. Fish in Kangarssuk were large, ranging in size from 220 to $367 \mathrm{~mm}$ and a considerable number were ready to spawn. All individuals caught at Kangarssuk were more than 5 years old, while ages of individuals in other populations were uniformly distributed. All had eaten chironomids and additionally a large number of individuals had preyed on benthic ostracods and Lepidurus arcticus.

\section{Annual fish growth rate and effects of climate variation}

Detailed results from multiple linear regressions are depicted in table 1 . Regressions were carried out with growth rate residuals $\left(G R_{t}\right)$ as response variable and one year delayed autoregressing $\left(G R_{t-1}\right)$, mean annual temperature $\left(\mathrm{T}_{\mathrm{a}}\right)$, mean summer temperature $\left(\mathrm{T}_{\mathrm{s}}\right)$, mean winter temperature $\left(\mathrm{T}_{\mathrm{w}}\right)$ and mean annual precipitation $\left(\mathrm{P}_{\mathrm{a}}\right)$ as predictor variables. None of the four weather parameters showed significant interdependence. Analyses of cohorts caught in 2004 were based on weather data from Qeqertarsuaq, while analyses from 1990 cohorts were carried out using data from Aasiaat.

Analyses of the Røde Elv individuals caught in 2004 ( $\mathrm{n}=$ 14) showed a negative effect of $T_{a}$ on the annual $G R_{t}$ together with a non-significant $G R_{t-1}\left(\mathrm{R}^{2}\right.$ total $=0.92 ; \mathrm{T}_{\mathrm{a}}: \mathrm{p}=$ $0.05 ; G R_{t-1}: \mathrm{p}=0.11$; Fig 1a). The otolith data from this sample allow regression with more than two predictor variables in only two cases but neither yielded any significant results (table 1). Otolith data from individuals caught in Røde Elv in 1990 ( $\mathrm{n}=14)$ by contrast, allowed simultaneous modelling of several predictor variables and $G R_{t}$. These data showed a significant positive relationship with $\mathrm{T}_{\mathrm{a}}$ and a significant negative relationship with $\mathrm{P}_{\mathrm{a}}\left(\mathrm{R}^{2}\right.$ total $=0.83 ; \mathrm{T}_{\mathrm{a}}: \mathrm{p}=0.03 ; \mathrm{P}_{\mathrm{a}}:=0.05 ; G R_{t-1}: \mathrm{p}=0.78 ;$ Fig 1b).

Data on annual $G R_{t}$ from the Kangarssuk individuals caught in $2004(\mathrm{n}=14)$ allowed simultaneous multiple linear regression with several predictor variables and the analysis yielded several significant relationships between $G R_{t}$ and $\mathrm{T}_{\mathrm{s}}$ and $\mathrm{T}_{\mathrm{w}}$, respectively (se Fig $2 \mathrm{a}, 2 \mathrm{~b}$ and table 1 ). For example, multiple linear regression with $G R_{t}$ and the predictor values $\mathrm{T}_{\mathrm{s}}, \mathrm{T}_{\mathrm{a}}$ and $G R_{t-1}$ showed a positive significant connection $\left(\mathrm{R}^{2}\right.$ total $=0.94 ; \mathrm{T}_{\mathrm{s}}: \mathrm{p}=0.04 ; \mathrm{T}_{\mathrm{a}}: \mathrm{p}=0.18$; $\left.G R_{t-1}: \mathrm{p}=0.66\right)$, while a similar regressing with $G R_{t}$ and the predictor variables $\mathrm{T}_{\mathrm{w}^{\prime}} \mathrm{T}_{\mathrm{a}}$ and $G R_{t-1}$ showed a negative significant relationship $\left(\mathrm{R}^{2}{ }_{\text {total }}=0.98 ; \mathrm{T}_{\mathrm{w}}: \mathrm{p}=0.04 ; \mathrm{T}_{\mathrm{a}}: \mathrm{p}=\right.$ $\left.0.81 ; G R_{t-1}: \mathrm{p}=0.36\right)$. Thus, $G R_{t}$ are significantly related negatively to $\mathrm{T}_{\mathrm{w}}$ and positively to $\mathrm{T}_{\mathrm{s}^{\prime}}$ without any significant $G R_{t-1}$.

Data on annual $G R_{t}$ from individuals caught in Kangarssuk in $1990(\mathrm{n}=10)$ allowed multiple linear regressions incorporating several predictor variables. A model incorporating $\mathrm{T}_{\mathrm{a}}, \mathrm{P}_{\mathrm{a}}$ and $G R_{t-1}$ showed a negative effect of $\mathrm{P}_{\mathrm{a}}$ on $G R_{t}\left(\mathrm{R}^{2}\right.$ total $=0.77 ; \mathrm{P}_{\mathrm{a}}:=0.07 ; \mathrm{T}_{\mathrm{a}}: \mathrm{p}=0.21 ; G R_{t-1}: \mathrm{p}=$ 0.09 ), while a model incorporating $\mathrm{T}_{\mathrm{w}}$ instead of $\mathrm{T}_{\mathrm{a}}$ further documented the relationship $\left(\mathrm{R}_{\text {total }}^{2}=0.8 ; \mathrm{P}_{\mathrm{a}}:=0.07 ; \mathrm{T}_{\mathrm{w}}: \mathrm{p}\right.$ $=0.17 ; G R_{t-1}: \mathrm{p}=0.09$; se also Fig $2 \mathrm{c}$ ). 
Table I: Statistical values from multiple linear regression modelling between growth rate residuals, autoregressing and climate parameters from Kangarssuk and Røde Elv in 2004 and 1990.

\begin{tabular}{|c|c|c|c|c|}
\hline Kangarssuk 2004 & $P$ & Coefficient & S.E. & $\mathbf{R}^{2}$ \\
\hline $\mathrm{T}_{\mathrm{a}} / \mathrm{GR}_{\mathrm{t}-\mathrm{I}}$ & $0.53 / 0.99$ & $9.2 / 0.01$ & $12.98 / 0.46$ & 0.15 \\
\hline $\mathrm{T}_{\mathrm{s}}^{a} / \mathrm{GR}_{\mathrm{t}-\mathrm{I}}$ & $0.04 / 0.73$ & 15.15/0.09 & $4.35 / 0.22$ & 0.80 \\
\hline $\mathrm{T}_{\mathrm{w}} / \mathrm{GR}_{\mathrm{t}-1}$ & $0.002 / 0.15$ & $-25.88 /-0.07$ & $1.09 / 0.03$ & $>0.99$ \\
\hline$P_{a} / G R_{t-1}$ & $0.24 / 0.77$ & $1.58 / 0.13$ & $1.09 / 0.39$ & 0.41 \\
\hline $\mathrm{T}_{\mathrm{s}} / \mathrm{T}_{\mathrm{a}} / \mathrm{GR}_{\mathrm{t}-1}$ & $0.04 / 0.18 / 0.66$ & $21.42 /-12.47 / 0.08$ & $4.35 / 6.16 / 0.16$ & 0.94 \\
\hline $\mathrm{T}_{\mathrm{w} / \mathrm{a}} \mathrm{T}_{\mathrm{a}} / \mathrm{GR}_{\mathrm{t}-1}$ & $0.04 / 0.81 / 0.36$ & $-25.78 / 0.38 /-0.07$ & I.5/I.2/0.04 & $>0.99$ \\
\hline $\mathrm{P}_{\mathrm{a}} / \mathrm{T}_{\mathrm{a}}^{\mathrm{d}} / \mathrm{GR}_{\mathrm{t}-1}$ & $0.27 / 0.43 / 0.69$ & $0.084 / 10.58 / 0.18 \mid$ & $0.06 / 10.71 / 0.4$ & 0.61 \\
\hline $\mathrm{T}_{\mathrm{s}} / \mathrm{P}_{\mathrm{a}} / \mathrm{GR}_{\mathrm{t}-1}$ & $0.05 / 0.14 / 0.36$ & $13.04 / 0.05 / 0.17$ & $2.87 / 0.02 / 0.14$ & 0.95 \\
\hline $\mathrm{T}_{\mathrm{w}}^{5} / \mathrm{P}_{\mathrm{a}}^{\mathrm{d}} / \mathrm{GR}_{\mathrm{t}-1}$ & $0.04 / 0.46 / 0.29$ & $-24.72 / 0.01 / 0.03$ & $0.94 / 0.06 / 0.08$ & $>0.99$ \\
\hline $\mathrm{T}_{s} / \mathrm{T}_{\mathrm{w}}^{\mathrm{d}} / \mathrm{GR}_{\mathrm{t}-1}$ & $0.96 / 0.07 / 0.42$ & $0.142 /-25.72 /-0.07$ & $2.09 / 2.83 / 0.05$ & $>0.99$ \\
\hline $\mathrm{T}_{\mathrm{s}} / \mathrm{T}_{\mathrm{a}} / \mathrm{P}_{\mathrm{a}} / \mathrm{GR}_{\mathrm{t}-1}$ & $0.09 / 0.24 / 0.21 / 0.31$ & $17.76 /-8.18 / 0.04 / 0.14$ & $2.37 / 3.21 / 0.01 / 0.08$ & 0.99 \\
\hline Røde Elv 2004 & $P$ & Coefficient & S.E. & $\mathbf{R}^{2}$ \\
\hline $\mathrm{T}_{\mathrm{a}} / \mathrm{GR}_{\mathrm{t}-1}$ & $0.05 / 11$ & $-13.34 / 1.59$ & $-1.84 / I .22$ & 0.92 \\
\hline $\mathrm{T}_{\mathrm{s}}^{\mathrm{s}} / \mathrm{GR}_{\mathrm{t}-1}$ & $0.18 / 0.72$ & $-5.75 /-0.21$ & $2.8 / 0.5$ & 0.73 \\
\hline $\mathrm{T}_{\mathrm{w}} / \mathrm{GR}_{\mathrm{t}-\mathrm{I}}$ & $0.99 / 0.59$ & $0.1 /-0.6$ & $7.4 / 0.8$ & 0.37 \\
\hline $\mathrm{P}_{\mathrm{a}} / \mathrm{GR}_{\mathrm{t}-1}$ & $0.30 / 0.66$ & $0.03 /-0.38$ & $0.02 / 0.61$ & 0.57 \\
\hline $\mathrm{T}_{\mathrm{s}} / \mathrm{T}_{\mathrm{a}} / \mathrm{GR}_{\mathrm{t}-1}$ & $0.84 / 0.36 / 0.4$ & $1.27 /-15.65 / 1.9$ & $4.95 / 9.97 / 1.39$ & 0.92 \\
\hline $\mathrm{P}_{\mathrm{a}} / \mathrm{T}_{\mathrm{a}} / \mathrm{GR}_{\mathrm{t}-1}$ & $0.59 / 0.23 / 0.31$ & $0.01 /-11.5 / 1.34$ & $0.01 / 4.31 / 0.72$ & 0.95 \\
\hline $\mathrm{T}_{\mathrm{s}}^{\mathrm{s}} / \mathrm{P}_{\mathrm{a}} / \mathrm{GR}_{\mathrm{t}-1}$ & $0.12 / 0.15 / 0.57$ & $-4.99 / 0.02 /-0.14$ & $0.96 / 0.01 / 0.17$ & $>0.99$ \\
\hline Kangarssuk 1990 & $P$ & Coefficient & S.E. & $\mathbf{R}^{2}$ \\
\hline $\mathrm{T}_{\mathrm{a}} / \mathrm{GR}_{\mathrm{t}-1}$ & $0.7 / 0.48$ & $-0.58 /-0.36$ & $1.39 / 0.46$ & 0.2 \\
\hline $\mathrm{T}_{\mathrm{s}} / \mathrm{GR}_{\mathrm{t}-1}^{\mathrm{t}-1}$ & $0.83 / 0.43$ & $-0.89 / 0.4$ & $3.97 / 0.45$ & 0.17 \\
\hline $\mathrm{T}_{\mathrm{w}} / \mathrm{GR}_{\mathrm{t}-1}$ & $0.55 / 0.42$ & $-0.33 /-0.39$ & $0.5 \mathrm{I} / 0.43$ & 0.24 \\
\hline$P_{a} / G R_{t-1}$ & $0.12 / 0.18$ & $-0.1 /-0.54$ & $0.05 / 0.33$ & 0.57 \\
\hline $\mathrm{T}_{\mathrm{s}} / \mathrm{T}_{\mathrm{a}} / \mathrm{GR}_{\mathrm{t}-1}$ & $0.92 / 0.77 / 0.58$ & $0.77 /-0.78 / 0.34$ & $6.8 / 2.42 / 0.55$ & 0.2 \\
\hline $\mathrm{T}_{\mathrm{w} / \mathrm{T}} \mathrm{T}_{\mathrm{a}}^{\mathrm{a}} / \mathrm{GR}_{\mathrm{t}-1}$ & $0.54 / 0.63 / 0.41$ & $-1.22 / 2.5 \mid /-0.55$ & I.77/4.73/0.56 & 0.31 \\
\hline $\mathrm{P}_{\mathrm{a}} / \mathrm{T}_{\mathrm{a}} / \mathrm{GR}_{\mathrm{t}-1}$ & $0.07 / 0.21 / 0.09$ & $-0.17 / 2.07 /-0.8$ & $0.06 / 1.31 /-0.8$ & 0.77 \\
\hline $\mathrm{T}_{\mathrm{s}} / \mathrm{P}_{\mathrm{a}} / \mathrm{GR}_{\mathrm{t}-1}$ & $0.53 / 0.15 / 0.22$ & $2.48 /-0.12 /-0.56$ & $3.52 / 0.06 / 0.36$ & 0.63 \\
\hline$T_{w} / P_{a} / G_{t-1}$ & $0.07 / 0.17 / 0.9$ & $-0.21 / 1.02 /-0.73$ & $0.07 / 0.56 / 0.29$ & 0.8 \\
\hline $\mathrm{T}_{\mathrm{s}} / \mathrm{T}_{\mathrm{w}} / \mathrm{GR}_{\mathrm{t}-1}$ & $0.91 / 0.63 / 0.5$ & $0.68 /-0.38 /-0.38$ & $5.25 / 0.7 / 0.5$ & 0.24 \\
\hline $\mathrm{T}_{\mathrm{s}}^{\mathrm{s}} / \mathrm{T}_{\mathrm{a}} / \mathrm{P}_{\mathrm{a}} / \mathrm{GR}_{\mathrm{t}-1}$ & $0.88 / 0.39 / 0.16 / 0.19$ & $-0.78 / 2.3 /-0.18 /-0.82$ & $4.53 / 2.11 / 0.08 / 0.42$ & 0.77 \\
\hline $\mathrm{T}_{\mathrm{w}}^{\mathrm{s}} / \mathrm{T}_{\mathrm{a}} / \mathrm{P}_{\mathrm{a}} / \mathrm{GR}_{\mathrm{t}-1}$ & $0.64 / 0.9 / 0.16 / 0.19$ & $0.83 / 0.46 /-0.21 /-0.75$ & 1.5/3.27/0.09/0.39 & 0.8 \\
\hline $\mathrm{T}_{\mathrm{s}} / \mathrm{T}_{\mathrm{w}}^{\mathrm{a}} / \mathrm{T}_{\mathrm{a}}^{\mathrm{a}} / \mathrm{GR}_{\mathrm{t}-1}$ & $0.65 / 0.51 / 0.56 / 0.43$ & $-5.91 /-2.47 / 7.24 /-0.9$ & $11.1 / 3.1 / 10.4 / 0.89$ & 0.39 \\
\hline $\mathrm{T}_{\mathrm{s}} / \mathrm{T}_{\mathrm{w}} / \mathrm{P}_{\mathrm{a}}^{\mathrm{a}} / \mathrm{GR}_{\mathrm{t}-1}$ & $0.75 / 0.31 / 0.14 / 0.17$ & I.19/0.94/-0.2I/-0.72 & $3.25 / 0.7 / 0.09 / 0.34$ & 0.81 \\
\hline $\mathrm{T}_{\mathrm{s}} / \mathrm{T}_{\mathrm{w}} / \mathrm{T}_{\mathrm{a}} / \mathrm{P}_{\mathrm{a}} / \mathrm{GR}_{\mathrm{t}-1}$ & $0.74 / 0.66 / 0.79 / 0.36 / 0.58$ & $4.5 \mathrm{I} / 2.19 /-3.56 /-0.25 /-0.54$ & $10.6 / 3.74 / 10.4 / 0.15 / 0.70$ & 0.83 \\
\hline Røde Elv 1990 & $P$ & Coefficient & S.E. & $\mathbf{R}^{2}$ \\
\hline$T_{a} / G_{t-1}$ & $0.3 / 0.62$ & $0.55 /-0.25$ & $0.46 / 0.46$ & 0.26 \\
\hline $\mathrm{T}_{\mathrm{s}} / \mathrm{GR}_{\mathrm{t}-\mathrm{I}}$ & $0.47 / 0.99$ & $1.12 / 0.002$ & $\mathrm{I} .4 \mathrm{I} / 0.49$ & 0.14 \\
\hline $\mathrm{T}_{\mathrm{w}} / \mathrm{GR}_{\mathrm{t}-1}$ & $0.56 / 0.66$ & $0.14 /-0.27$ & $0.22 / 0.56$ & 0.1 \\
\hline $\mathrm{P}_{\mathrm{a}} / \mathrm{GR}_{\mathrm{t}-1}$ & $0.6 / 0.91$ & $-0.02 / 0.07$ & $0.03 / 0.56$ & 0.08 \\
\hline $\mathrm{T}_{\mathrm{s}} / \mathrm{T}_{\mathrm{a}} / \mathrm{GR}_{\mathrm{t}-1}$ & $0.82 / 0.51 / 0.64$ & $-0.7 / 0.76 /-0.37$ & 2.86/I.0I/0.7I & 0.28 \\
\hline $\mathrm{T}_{\mathrm{w} / \mathrm{a}} \mathrm{T}_{\mathrm{a}} / \mathrm{GR}_{\mathrm{t}-1}$ & $0.25 / 0.17 / 0.68$ & $-0.78 / 2.29 / 0.24$ & $0.54 / 1.28 / 0.53$ & 0.57 \\
\hline $\mathrm{P}_{\mathrm{a}} / \mathrm{T}_{\mathrm{a}} / \mathrm{GR}_{\mathrm{t}-1}$ & $0.05 / 0.03 / 0.78$ & $-0.06 / 1.19 / 0.08$ & $0.02 / 0.32 / 0.27$ & 0.83 \\
\hline $\mathrm{T}_{\mathrm{s}} / \mathrm{P}_{\mathrm{a}} / \mathrm{GR}_{\mathrm{t}-1}$ & $0.1 / 0.11 / 0.22$ & $3.25 /-0.06 / 0.72$ & $1.37 / 0.03 / 0.47$ & 0.68 \\
\hline $\mathrm{T}_{\mathrm{w}} / \mathrm{P}_{\mathrm{a}} / \mathrm{GR}_{\mathrm{t}-1}$ & $0.09 / 0.09 / 0.72$ & $0.55 /-0.07 /-0.15$ & $0.22 / 0.03 / 0.38$ & 0.7 \\
\hline $\mathrm{T}_{\mathrm{s}} / \mathrm{T}_{\mathrm{w}} / \mathrm{GR}_{\mathrm{t}-1}$ & $0.72 / 0.97 / 0.98$ & I.05/0.01/-0.02 & $2.64 / 0.40 / 0.88$ & 0.14 \\
\hline $\mathrm{T}_{\mathrm{s}} / \mathrm{T}_{\mathrm{a}} / \mathrm{P}_{\mathrm{a}} / \mathrm{GR}_{\mathrm{t}-\mathrm{I}}$ & $0.54 / 0.23 / 0.09 / 0.54$ & $1.2 / 0.9 /-0.06 / 0.32$ & $\mathrm{I} .6 \mathrm{I} / 0.53 / 0.02 / 0.43$ & 0.87 \\
\hline $\mathrm{T}_{\mathrm{w}} / \mathrm{T}_{\mathrm{a}} / \mathrm{P}_{\mathrm{a}} / \mathrm{GR}_{\mathrm{t}-1}$ & $0.84 / 0.31 / 0.21 / 0.77$ & $-0.12 / 1.42 /-0.05 / 0.14$ & $0.54 / 1.06 / 0.03 / 0.40$ & 0.84 \\
\hline $\mathrm{T}_{\mathrm{s}} / \mathrm{T}_{\mathrm{w}} / \mathrm{T}_{\mathrm{a}} / \mathrm{GR}_{\mathrm{t}-1}$ & $0.72 / 0.34 / 0.72 / 0.92$ & $-1.07 /-0.81 / 2.68 / 0.08$ & $2.63 / 0.64 / 1.78 / 16.0$ & 0.60 \\
\hline $\mathrm{T}_{\mathrm{s}} / \mathrm{T}_{\mathrm{w}} / \mathrm{P}_{\mathrm{a}} / \mathrm{GR}_{\mathrm{t}-1}$ & $0.27 / 0.26 / 0.09 / 0.54$ & $2.05 / 0.36 /-0.08 / 0.34$ & $1.36 / 0.23 / 0.02 / 0.45$ & 0.86 \\
\hline $\mathrm{T}_{\mathrm{s}} / \mathrm{T}_{\mathrm{w}} / \mathrm{T}_{\mathrm{a}}^{\mathrm{a}} / \mathrm{P}_{\mathrm{a}} / \mathrm{GR}_{\mathrm{t}-1}$ & $0.7 / 0.92 / 0.79 / 0.38 / 0.7$ & $1.37 / 0.1 / 0.68 /-0.07 / 0.31$ & $2.68 / 0.8 / 1.97 / 0.05 / 0.61$ & 0.87 \\
\hline
\end{tabular}

Statistical significant results are shown in bold $\left(T_{a}=\right.$ Mean annual temperature; $T_{s}=$ Mean summer temperature; $T_{w}=$ Mean winter temperature; $P_{a}$ $=$ Mean annual precipitation; $G R_{t-1}$ : autoregression). 

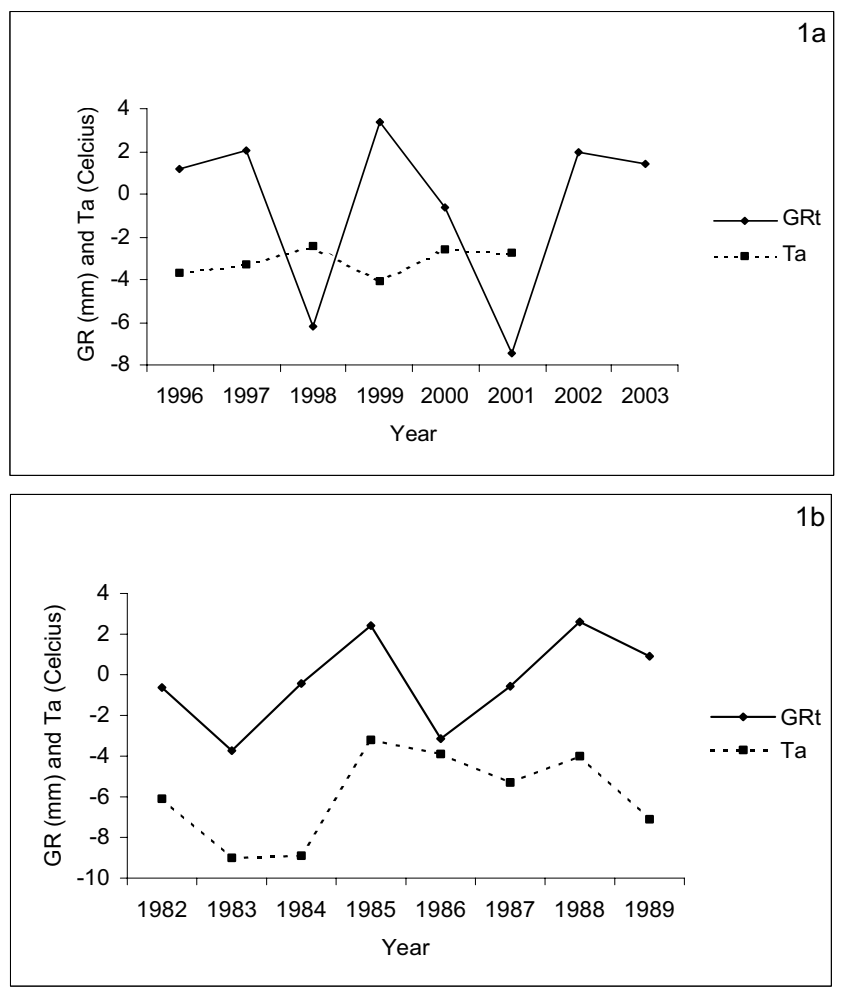

Figure I

Growth rates obtained from otoliths of Arctic charr caught in Røde Elv 2004 and 1990 plotted against fluctuations in mean annual temperature. (a) Data from 2004 showing $G R_{t}\left(G R_{t}=\right.$ Growth rate residuals $)$ in Arctic charr from Røde Elv plotted against fluctuations in $T_{a}\left(T_{a}\right.$ = Mean annual temperature). (b) Data from 1990 showing $G R_{t}$ in Arctic charr from Røde Elv plotted against fluctuations in $T_{a}$ data from Aasiaat.

Comparison of mean growth rate from the two time series Otolith derived changes in mean values of fork length estimated means $\left(\mathrm{F}_{\mathrm{em}}\right)$, and thereby growth, were assessed from the periods 1982-1989 and 1995-2003, respectively. An ANOVA test was performed to evaluate the differences between the time series. The estimated rates of growth from the Røde Elv samples from 1982-1989 were significantly larger compared with the 1995-2003 sample ( $p=0.008 ;$ d.f. = 7; Fig 3a). The opposite was the case among fish from Kangarssuk. Here, rates of growth were larger in the period 1991-2003 compared to 1982-1989 $(\mathrm{p}=0.0004 ;$ d.f. $=7$; Fig 3b).

\section{Discussion}

Our findings suggest that the climatic variation observed in the Arctic during the last two decades has already had a significant effect on life history parameters in Arctic charr. This is evident from the complex coupling between annual growth rates and fluctuations in mean annual temperatures and means annual precipitation together with marked changes in the annual mean growth rate history between 1990 and 2004. Impacts of climate on animal populations have been demonstrated before for several species in the Arctic e.g. musk oxen, reindeer, vole and wolf [11]. These species are generally morphologically and ecologically more uniform than Arctic charr which is one of the most polymorphic vertebrate species [12]. Consequently, several difficulties would be anticipated addressing the modelling analyses without consideration for known variation in life history and hence somatic growth rates for different morphs - e.g. anadromous versus residents. The homogenous and landlocked Arctic charr in Røde Elv and Kangarssuk were therefore the only suitable populations to study annual climatic impact on growth of an Arctic population. The mean air temperatures in August at sample sites have increased from $4.9^{\circ} \mathrm{C}$ in 1991 to $9.1^{\circ} \mathrm{C}$ in 2001 [10]. Consistent with our prediction this appears to have retarded the rate of growth of fish in one population (Røde Elv) but, contrary to our expectations to have stimulated annual rates of growth in another (Kangarssuk). We suggest that the difference in response might be due to local differences in the dynamic between energy demand in fish and food supply.

An increase in ambient temperature leads to increase in metabolic rate, which in turn leads to an increased energy demand. If increased metabolic demand is not matched by a corresponding increase in food supply, the net outcome is likely to be a reduction in fitness and, hence, growth rate of the fish [13]. Røde Elv already is a poor habitat for charr, as indicated by the small maximum size of fish there $(16.9 \mathrm{~cm})$, and higher temperatures may therefore have resulted in an increased metabolic demand which the fish were unable to adequately meet. At Kangarssuk, in contrast, there appear to have been an increase in food supply evidenced by the appearance of benthic ostracods and Lepidurus arcticus as new food items in 2004 compared to prior sampling at the locality [2].

After showing climate dependent growth rates in fish caught in both 1990 and 2004, the time series were compared. The data demonstrated a difference between $\mathrm{F}_{\mathrm{em}}$ from the 1990 and 2004 time series at both Røde Elv and Kangarssuk. The charr population in Røde Elv in 2004 had experienced a decline in $\mathrm{F}_{\mathrm{em}}$ compared to 1990. As mentioned, several factors such as elevated temperatures, increased turbidity or difference in prey composition may explain this tendency. The definition of optimum temperature for growth is only valid under the assumption that there is no food limitation [14]. Hence, the temperature at which the growth rate is maximised is progressively shifted to lower temperature values, as the amount of available food is decreased [13]. Our data from Røde Elv is in accordance with the above mentioned scenario showing a significant positive influence of $\mathrm{T}_{\mathrm{a}}$ on the pop- 


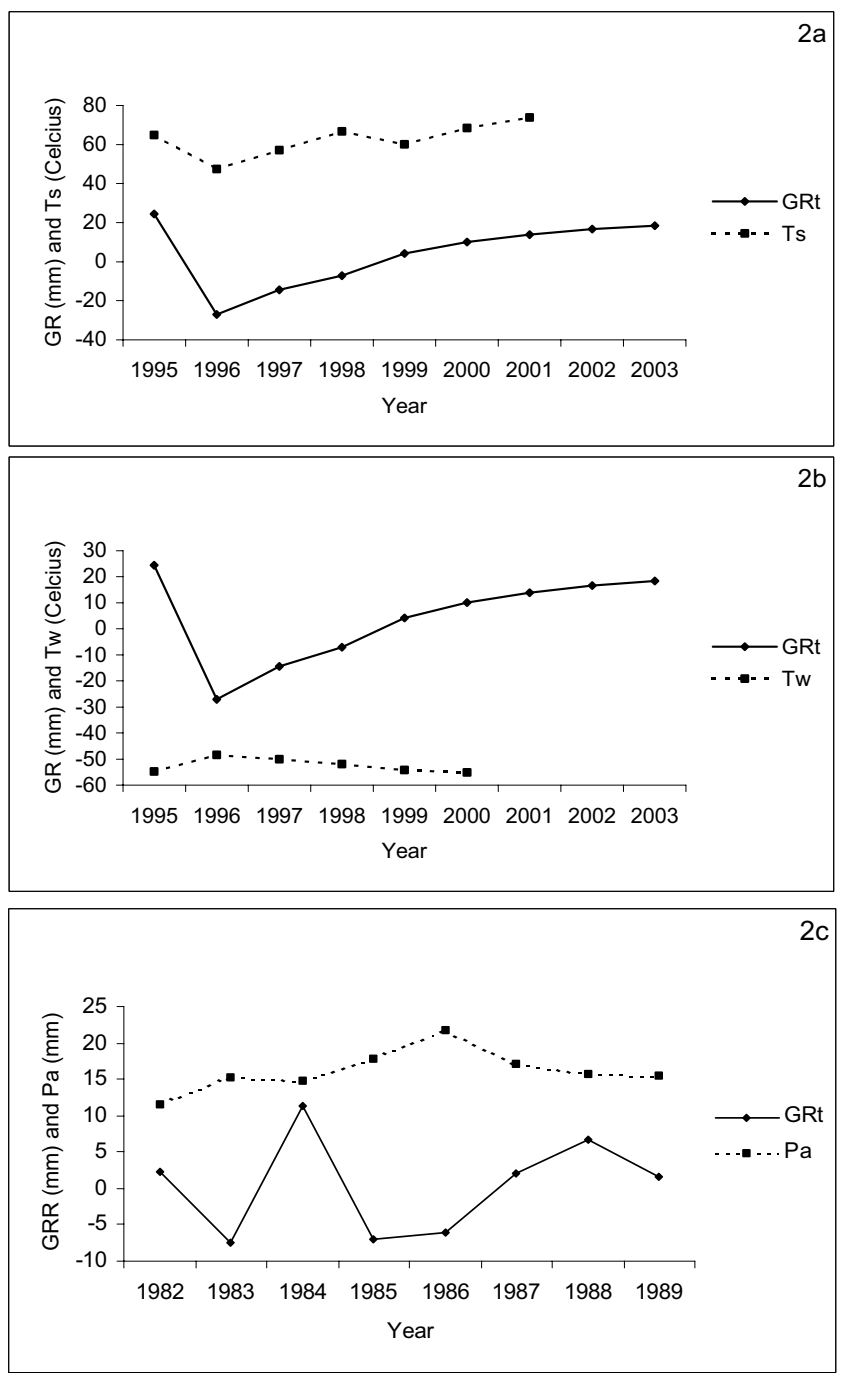

Figure 2

Growth rates obtained from otoliths of Arctic charr caught in Kangarssuk 2004 and 1990 plotted against fluctuations in mean annual temperature and precipitation. (a) Data from 2004 showing $G R_{t}\left(G R_{t}=\right.$ Growth rate residuals) in Arctic charr from Kangarssuk plotted against fluctuations in $T_{s}\left(T_{s}=\right.$ Mean summer temperature) (b) and $T_{w}$ multiplied by 5 ( $T_{w}=$ Mean winter temperature). (c) Data obtained from otoliths collected in 1990 showing $G R_{t}$ in Arctic charr from Kangarssuk plotted against fluctuations in $\mathrm{P}_{\mathrm{a}}$ divided by 20 from Aasiaat $\left(P_{a}=\right.$ Mean summer temperature).

ulation sampled in 1990, while samples from 2004 show a significant negative influence of $\mathrm{T}_{\mathrm{a}}$ on the annual growths rate. Thus, changes in $\mathrm{F}_{\mathrm{em}}$ between 1990 and 2004 supports our hypothesis that in Røde Elv energy resources cannot sustain higher metabolic rates created by increasing temperatures. Consequently, there has been a drop in fitness mirrored in the reduced growth rate.
From the Kangarssuk data it is evident that $\mathrm{F}_{\mathrm{em}}$ values are considerably larger in the 2004 compared to 1990. Furthermore, all individuals caught in Kangarssuk in 2004 had large skin infections, which were not observed in 1990 [2]. Several studies have shown that parasitic, viral and bacterial infections in fish are positively correlated to ambient temperatures [15-17]. It seems therefore reasonable that the infections could be a consequence of the increase temperature in the lake. In addition, we did not catch any juvenile individuals in Kangarssuk, which is also contrary to studies in 1990 [2] and the other sampled localities. The fact that it was impossible to catch fish below age $5+$ suggests that the population have limited breeding success possibly caused by the elevated temperatures in the shallow lake (maximum depth 7 meters).

\section{Conclusion}

Results from the present study show that temperature has a notable impact on the growth rates of two cold adapted Arctic charr populations. The populations investigated have been affected in different ways. Thus, our results show that the effect of warming on Arctic charr growth, depend on the magnitude of change and on local factors such as the morphometry of the system in question (river or lake), pathogens and food resources. Even though that this study is based on two localities with a limited sample size, the results are significant and indicate that the current increase in temperature is already having an impact on the Arctic populations.

\section{Methods}

Study sites

The study was carried out on Disko Island $\left(69^{\circ} 15^{\prime} \mathrm{N}, 53^{\circ}\right.$ $31^{\prime} \mathrm{W}$ ) off the west coast of Greenland. Six study sites (four lakes and two rivers) were chosen known to have populations of Arctic charr. Data on wind, temperature, precipitation and albedo were obtained from records at the weather survey station at Qeqertarsuaq on Disko (1990 to 2001) and similar from the Danish Meteorological Institute's [18] climate station in Aasiaat on the west coast of Greenland approximately $65 \mathrm{~km}$ from Qeqertarsuaq (1981 to 1989 ).

\section{Sampling and treatment of material}

Water temperatures were measured with depths at all study sites using a Hydrolab multisonde. Fish were caught in July and August 2004 with multi mesh gill net (Faarups Specialnet, Denmark) of a type proposed for monitoring use in Nordic countries (referred to as 'biological survey gill nets'; Nordic Norm) designed to catch representatively across a population. The nets were 40 meters long and composed of 12 mesh sizes: 29, 35, 5, 15.5, 24, 12.5, 8, $55,10,6.25,19.5$ and $43 \mathrm{~mm}$. Sampling was carried out using randomized pelagic and littoral settings for each locality. The pelagic nets were placed parallel to the shore, 

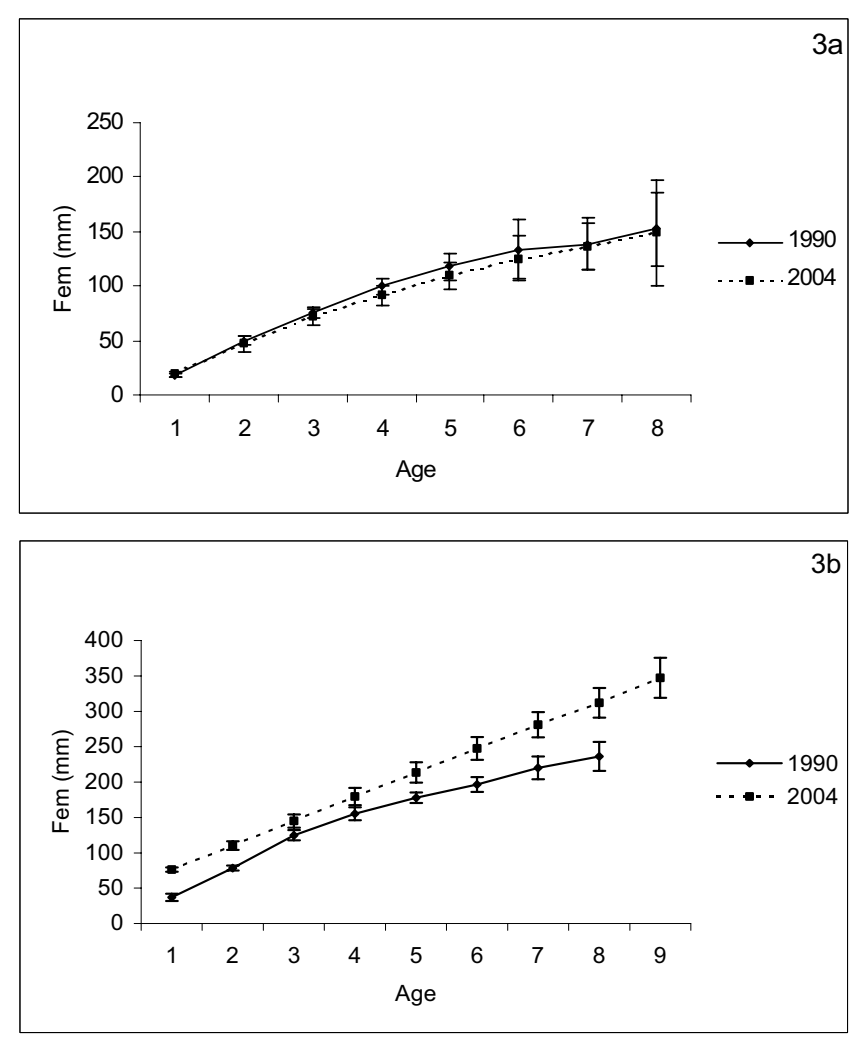

Figure 3

Comparison of growth rates of Arctic charr from Kangarssuk and Røde Elv sampled in 1990 and 2004.

(a) Changes in values of fork length estimated means showing growth during life history of fish living at Røde Elv in 19821989 and $1995-2003\left(\mathrm{~F}_{\mathrm{em}}=\right.$ Values of fork length estimated means; error bars: $\pm 95 \%$ C.L; ANOVA: $p=0.008$; d.f. $=7$ ) and (b) at Kangarssuk in respectively 1982-1989 and 1995$2003\left(\mathrm{~F}_{\mathrm{em}}=\right.$ Values of fork length estimated means; Error bars: $\pm 95 \%$ C.L; ANOVA: $p=0.0004$; d.f. $=7$ ).

while the littoral nets were set perpendicular to the shore. Specimens from the two rivers were obtained by angling (Nipisat Elv) or by hand nets and multi mesh gill nets (Røde Elv).

Populations suitable for climate studies were selected using principal component analysis (PCA) conducted in PCord- 4 to examine the homogeneity following standard procedures detailed in [19] with respect to morphological quantitative characters (fork length, weight, age, mouth depth, mouth depth relative to fork length and condition factor [20]) and categorical characters (colour, sex, gonad maturity and stomach content).

Otoliths (sagittae) were sampled from all fish and subsequently mounted on a glass slide using resin at $140^{\circ} \mathrm{C}$ with the sulcus facing down and polished to enhance the annular ring structure. The age of the fish was estimated to the nearest year by counting of annual rings and by making transects to quantify the distance between annular rings using digital video microscopy with the software Image Pro Plus 5.0 (MediaCybernetics). Transects were placed as close to a downward angel of $90^{\circ}$ to rostrum as possible in all examinations.

\section{Assessment of somatic growth}

Measurements of otolith radius, fork length (F) and age at time of capture were used in constructing an IndividualCharacter matrix for each locality. We applied a recent model for growth back-calculation developed by Morita and Matsuishi [21] which takes into account that growth of fish (fork length) may be allometrically uncoupled from growth of their otolith. Multiple regression analyses were conducted using SYSTAT 8.0 (Systat Software Inc.) and back-calculated F-values were applied for calculation of growth rates using the simple relationship between body size at succeeding years:

$G_{t}=F_{t+1}-F_{t}$

where $G_{t}$ is the estimated growth rate at age $t$, and $F_{t+1}$ and $F_{t}$ are fork lengths estimated by back-calculation at age $t$ and $t+1$. To allow detection of signals from climate conditions on growth rates, the effect of ontogenetic development in every individual was subtracted from the $G$ values. We assumed a simple additive relationship between the effects of ontogenetic development and environmental conditions on the realized growth rate of the individual:

$G_{t}=f(O)+g(E)$

where $O$ is ontogenetic stage, $E$ is the sum of environmental conditions and $f$ and $g$ are mathematical functions. Thus, to reveal the effects of climate, which are inherent in $E$, we subtracted the $O$-impact from the estimated $G_{t}$ and obtained what was termed annual growth rate residuals $\left(G R_{t}\right)$ :

$G R_{t}=G_{t}-f(O)$

where the functional values of $O$ were computed for each locality and for the total pooled data set by fitting a logarithmic function to the age-determined growth-tendency for the individual sample. This was done by logistic curvefitting using the least-squares-method [22]. The resulting $G R_{t}$ values for each individual were assigned to the concurrent calendar year, thus obtaining the final time-individual matrix consisting of the growth rates for each individual. The mean growth tendency in the population was calculated annually and contrasted to variation in annual temperatures and precipitation. 


\section{Modelling annual growth and climatic variation}

Three annual levels of analysis were conducted. First, the constructed time series for annual fish growth and climatic variation, assessed by the parameters $T_{a^{\prime}}, T_{s^{\prime}} T_{w}$ and $\mathrm{P}_{\mathrm{a}^{\prime}}$, were depicted graphically for visual tendency interpretation. The Product Moment Correlation Coefficient $r$ was calculated for opposed time series of fish growth and climate variables.

Secondly, multiple linear regressions were carried out (Systat Software Inc.) regressing $G R_{t}$ for each locality on $\mathrm{T}_{\mathrm{a}^{\prime}} \mathrm{T}_{\mathrm{s}^{\prime}}, \mathrm{T}_{\mathrm{w}}$ or $\mathrm{P}_{\mathrm{a}^{\prime}}$ respectively, incorporating one year delayed autoregressing $\left(G R_{t-1}\right)$ :

$$
G R_{t}=\alpha+\gamma G R_{t-1}+x_{t} \beta
$$

where $x_{t}$ is the mean climate parameter for temperature and precipitation and $\alpha, \beta$ and $\gamma$ are regression constants.

Finally, to evaluate the impact of long-term climate change, we compared estimated growth curves between the two sampled time periods within each of the two landlocked populations. The growth curves formed a continuum from respectively 1982-1989 and 1995-2003. Data from 1990 and 2004 could not be used since the growth season had not finish at the time of sampling. The population means of the individual fork length estimates were tested by an ANOVA test [22] and plotted with corresponding standard errors of the estimate for each year. A statistical level of significance of $5 \%(p \leq 0.05)$ was chosen for all analyses.

$$
\begin{aligned}
& \text { Abbreviations } \\
& F=\text { Fork length } \\
& \mathrm{F}_{\mathrm{em}}=\text { Fork length estimated means } \\
& F_{t}=\text { Calculated fork lengths at age } \mathrm{t} \\
& F_{t+1}=\text { Calculated fork lengths at age } \mathrm{t}+1 \text { year } \\
& G=\text { Calculated growth rate } \\
& G R_{t}=\text { Growth rate residual } \\
& G R_{t-1}=\text { Growth rate residual incorporating a factor of } \\
& \text { autoregressing }
\end{aligned}
$$

$\mathrm{P}_{\mathrm{a}}=$ mean annual precipitation

$\mathrm{T}_{\mathrm{a}}=$ mean annual temperature

$\mathrm{T}_{\mathrm{s}}=$ mean summer temperature

$\mathrm{T}_{\mathrm{w}}=$ mean winter temperature

\section{Authors' contributions}

All authors contributed to the fieldwork. DMK, TRJ and RKL carried out analyses of otoliths, while DMK and TRJ carried out statistical analyses. KSC and MCF conceived of the study and DMK drafted the manuscript.

\section{Additional material}

\section{Additional File 1}

Principal Component Analysis of individual fish morphology and stomach content, showing the two axes of greatest explanatory power. Morphological quantitative characters included in analyses were fork length, weight, age, mouth depth, mouth depth relative to fork length and condition factor together with the following categorical characters colour, sex, gonad maturity and stomach content. Notice how Kangarssuk and Røde Elv individuals are closely scattered together indicating more homogeneous populations compared with the other sampled populations (Localities: $1(k)=$ Kangarssuk; $2(r)=$ Røde Elv; $3(\mathrm{~m} / \mathrm{l})=$ Mellems $\varnothing /$ Langes $\sigma ;$ $4(p)=$ Porsils $\sigma ; 5(n)=$ Nipisat. $R^{2}$ for vertical axis $=0.75$ and horizontal axis $=0.23$ ).

Click here for file

[http://www.biomedcentral.com/content/supplementary/14726785-6-10-S1.doc]

\section{Acknowledgements}

We wish to thank the crew of Porsild for their assistance during fieldwork, scientific director Rasmus Ejnæs from Arctic Station for access to climate data and Henrik Mosegaard from the Danish Institute for Fisheries Research for instruction and use of equipment. In addition we thank Nicholas Tyler for help with the manuscript.

\section{References}

I. Hansen B, Berggreen UC, Sørensen TB: Grønlands ferskvandsfisk. En undersøgelse af fjeldørredbestande på Disko. Edited by: Pape T, Hansen B and Hansen J. Copenhagen, Copenhagen University; 1983:37-103.

2. Mordhorst J, Due TT: Fjeldørreden (Salvelinus alpinus) og dens parasitter på Disko. Edited by: Andersen $P$, Duvel $L$ and Hansen OS. Copenhagen, Copenhagen University; 1990:235-272.

3. Jobling M: Temperature and growth: modulation of growth rate via temperature change. In: Global warming: Implications for freshwater and marine fish. In Global warming: Implications for freshwater and marine fish Edited by: Wood CM and D.G.McDonald . Cambridge, Cambridge University Press; 1996:225-253

4. Eckert R, Randall D, Augustine G: Animal Physiologi 3rd edition. New York, W.H. Freeman and Company; 1988: I-683.

5. Magnuson JJ, Crowder LB, Medvick PA: Temperature as an ecological resource. American Zoologist 1979, 19:331-343.

6. Gillet C: Egg production in an Arctic charr (Salvelinus alpinus L.) brood stock: effects of temperature on the timing of spawning and the quality of eggs. Aquatic Living Resources I991, 4:109-116.

7. Jungwirth $M$, Winkler $\mathrm{H}$ : The temperature dependence of embryonic development of grayling (Thymallus thymallus), Danube salmon (Hucho hucho), Arctic charr (Salvelinus alpinus) and Brown trout (Salmo trutta fario). Aquaculture 1984, 38:3I5-327.

8. Steiner V: Experiments towards improving the culture of Arctic charr (Salvelinus alpinus L.). In Biology of the Arctic Charr, Proceedings of the International Symposium on Arctic Charr Edited by: Johnson L and Burns BL. Winnipeg, University of Manitoba Press; |984:509-52|. 
9. Box JE: Survey of Greenland instrumental temperature records: 1973-200I. International Journal of Climatology 2005, 22:1829-1847.

10. Hansen BU, Humlum O, Nielsen N: Meteorological Observations 2002 at the Arctic Station, Qeqertasuaq $\left(6^{\circ} 15^{\prime} \mathrm{N}\right)$, Central West Greenland. Danish Journal of Geography 2003, 103:93-97.

II. Post E, Forchhammer MC: Synchronization of animal population dynamics by large-scale climate. Nature 2002, 420: $168-|7|$.

12. Adams CE, Huntingford FA: Incipient speciation driven by phenotypic plasticity? Evidence from sympatric populations of Arctic charr. Biological Journal of the Linnean Society 2004, 8I:6II-6I8

13. Russell NR, Fish JD, Wootton RJ: Feeding and growth of juvenile sea bass: The effect of ration and temperature on growth rate and efficiency. Journal of Fish Biology 1996, 49:206-220.

14. Jobling $M$ : Temperature tolerance and the final preferendum - rapid methods for the assessment of optimum growth temperatures. Journal of Fish Biology 1981, 19:439-455.

15. Decostre A, Haesebrouck F, Turnbull JF, Charlier G: Influence of water quality and temperature on adhesion of high and low virulence Flavobacterium columnare strains to isolated gill arches. Journal of Fish Diseases 1999, 22: I-I I.

16. Cecchini S, Saroglia M, Berni R, Cognetti-Varriale AM: Influence of temperature on the lifecycle of Diplectanum aequans (Monogenea, Diplectanidae), parasitic on sea bass, Dicentrarchus labrax (L.). Journal of Fish Diseases 1998, 2 1:73-75.

17. Tucker CS, Somerville C, Wootten R: The effect of temperature and salinity on the settlement and survival of copepodids of Lepeophtheirus salmonis (Krøyer, 1 837) on Atlantic salmon, Salmo salar L. Journal of Fish Diseases 2000, 23:309-32I.

18. McCune B, Grace JB: Analysis of Ecological Communities. Gleneden Beach Oregon, MjM Software Design; 2002: I-284.

19. Reid DP, Szanto A, Glebe B, Danzmann RG, Ferguson MM: QTL for body weight and condition factor in Atlantic salmon (Salmo salar): comparative analysis with rainbow trout (Oncorhynchus mykiss) and Arctic charr (Salvelinus alpinus). Heredity 2005, 94:166-172.

20. Morita K, Matsuishi T: A new model of growth back-calculation incorporating age effect based on otoliths. Canadian Journal of Fish and Aquatic Science 200I, 58:1805-18II.

21. Sakal RR, Rohlf F): Biometry: the principle and practice of statistics in biological research 3rd edition. New York, W.H. Freman and co.; 1995: I-887.

Publish with Bio Med Central and every scientist can read your work free of charge

"BioMed Central will be the most significant development for disseminating the results of biomedical research in our lifetime. "

Sir Paul Nurse, Cancer Research UK

Your research papers will be:

- available free of charge to the entire biomedical community

- peer reviewed and published immediately upon acceptance

- cited in PubMed and archived on PubMed Central

- yours - you keep the copyright
BioMedcentral 